\title{
HUBUNGAN ANTARA PARITAS DAN PENGETAHUAN TENTANG IMUNISASI TETANUS TOXOID DENGAN KELENGKAPAN IMUNISASI TETANUS TOXOID PADA IBU HAMIL TRIMESTER III
}

\author{
Wilda Nur Azizah, Shanti Ariandini, Annisa Fitri Rahmadini \\ Akbid Prima Husada Bogor \\ wildanurazizah5@gmail.com
}

\begin{abstract}
Abstrak
Cakupan imunisasi TT di Indonesia masih tergolong cukup rendah, ini dapat dilihat dengan jumlah ibu hamil sebanyak 5.290.235 yang melakukan TT1 sebanyak 1.239.173 $(23,4 \%)$ dan untuk TT2 sebanyak 1.155 .907 (21,8\%). Tujuan penelitian ini adalah untuk mengetahui Hubungan paritas dan pengetahuan tentang imunisasi Tetanus Toxoid dengan kelengkapan imunisasi Tetanus Toxoid pada ibu hamil trimester III di BPM Ida Ningsih Tahun 2021. Metode penelitian ini menggunakan metode deskriptif analitik dengan desain pendekatan Cross-sectional, kemudian data diolah dengan menggunakan uji chi square. Populasi ibu hamil yang melakukan imunisasi TT di BPM Ida Ningsih Tahun 2021 sebanyak $107 \mathrm{ibu}$ hamil yang diberikan imunisasi TT 1 sebanyak (36.2 \%) ibu hamil dan TT 2 sebanyak (26,9\%). Sampel dalam penelitian ini sebanyak 84 orang responden. Hasil uji statistik diperoleh nilai $p$ value $=0,002(p<\alpha)$ maka dapat disimpulkan adanya hubungan antara Paritas dengan Kelengkapan Imunisasi Tetanus Toxoid, dan diperoleh nilai $\mathrm{p}$ value $=0,006(\mathrm{p}<\alpha)$ maka dapat disimpulkan adanya hubungan antara Pengetahuan Tentang Imunisasi Tetanus Toxoid dengan Kelengkapan Imunisasi Tetanus Toxoid pada Ibu Hamil Trimester III di BPM Ida Ningsih Tahun 2021. Saran dalam penelitian ini adalah hasil penelitian ini dapat digunakan sebagai bahan informasi dan masukan bagi petugas kesehatan dalam memberikan penyuluhan di BPM Ida Ningsih Tahun 2021.
\end{abstract}

Kata Kunci: Imunisasi Tetanus Toxoid, Paritas, Pengetahuan. 
JOURNAL OF MIDWIFERY CARE :

VOL. 02 No. 01, DESEMBER 2021

DOI : $\underline{10.34305 / J M C . V 2 I 01.361}$

\section{Pendahuluan}

Menurut dari Organisasi Kesehatan Dunia (WHO), negara-negara berkembang sebanyak $99 \%$ kematian ibu pada tahun 2018. Sekitar 830 wanita meninggal setiap hari akibat kehamilan dan persalinan penyebab persalinan lainnya yang dapat dicegah. Hingga 7000 bayi meninggal setiap hari di seluruh dunia; Minggu pertama 3/4 kematian neonatal, dengan $40 \%$ terjadi selama 24 jam pertama. Setelah lahir dan selama beberapa hari pertama, perawatan BBL di bawah standar, dan kematian neonatal terkait dengan kualitas layanan persalinan (World Health Organization (WHO), 2018).

Menurut Kementerian Republik Indonesia (Kemenkes), dari 100.000 kelahiran hidup pada tahun 2018, 305 kematian ibu dan 29/1.000 kematian bayi di Indonesia. Angka kematian ibu (AKI) bisa mencapai 305 per 100.000 kelahiran hidup, sedangkan angka kematian bayi bisa mencapai 29 per 1.000 kelahiran hidup (World Health Organization (WHO), 2018).

Angka Kematian Ibu (AKI) di Jawa Barat sebesar 76,03 per 100.000 kelahiran hidup pada tahun 2017. Menurut Profil Kesehatan Kabupaten/Kota, pada tahun 2017 tercatat 696 kematian ibu
Ciptaan disebarluaskan di bawah

Lisensi Creative Commons Atribusi-

NonKomersial-BerbagiSerupa 4.0 Internasional.

(76,03/100.000 KH), turun dari tahun 2016 yang tercatat 799 kematian ibu. Jumlah kematian ibu adalah 183 orang $(19,9 / 100.000), \quad 224 \quad$ orang $(24,47 / 100.000 \mathrm{KH}), \quad$ dan 289 orang (31.57/100,00KH) untuk Ibu Bersalin dan 289 orang $(31.57 / 100,00 \mathrm{KH})$ untuk Ibu Nifas (Kementerian Kesehatan RI, 2017a).

Angka kematian bayi (AKB) dihitung dengan menggunakan laporan rutin dari Profil Kesehatan Provinsi Jawa Barat. Pada tahun 2018, terdapat 2.221 kasus Asfiksia, 6 kasus Tetanus, 82 kasus Sepsis, 303 kasus kelainan, dan 433 penyakit lainnya, sehingga mengakibatkan 1.049 kematian bayi BBLR (Kementerian Kesehatan RI, 2017a).

Pada tahun 2017, Ibu hamil yang mendapatkan pelayanan prenatal care (K4) konvensional sebanyak $98,08 \%$ dari total., total cakupan kunjungan nifas (KF3) sebesar 97,43\%, memenuhi target pelayanan minimal $90 \%$, dan total cakupan pelayanan neonatal pertama. kunjungan (KN1) sebesar 95 persen di Bogor (Profil Kesehatan Dinkes Kota Bogor, 2017).

Informasi berikut ini berasal dari studi WHO tentang situasi kesehatan penduduk tahun 2019, serta perbandingan jumlah kematian akibat berbagai penyakit terdapat 540.000 kematian akibat campak 
JOURNAL OF MIDWIFERY CARE :

VOL. 02 No. 01, DESEMBER 2021

DOI : $\underline{10.34305 / J M C . V 2 I 01.361}$

(morbility, campak), 249.000 kematian dari pertusis, 198.000 kematian akibat tetanus neonatorum, 4.000 kematian akibat difteri, dan 1000 kematian akibat poliomielitis (Lisnawati, 2011).

Menurut laporan Kementerian Kesehatan tahun 2018, cakupan vaksin TT di Indonesia masih cukup rendah, terlihat dari 5.290,235 ibu hamil yang mendapat TT1 (23,4\%), dan 1.155.907 ibu hamil yang mendapat TT2 (21,8 persen). Karena cakupan vaksin Tetanus Toxoid yang tidak memadai, 9,8\% (18.032) dari 184 ribu bayi baru lahir hidup di Indonesia akan meninggal (Dinas Kesehatan, 2018).

Toksoid tetanus yang diberikan oleh tenaga kesehatan pemerintah yang berpendidikan dan berkualitas, serta fasilitas kesehatan yang memadai untuk wanita usia subur (WUS) atau wanita hamil, tidak cukup untuk melindungi neonatus dari tetanus; sikap dan perilaku juga harus diperiksa. penting. Dalam hal ini perilaku sehat keluarga, khususnya ibu sangat berpengaruh terhadap kesehatan. Banyak elemen, termasuk paritas, pengetahuan, sikap, kepercayaan, dan tradisi, yang memengaruhi perilaku seseorang atau masyarakat, termasuk perilaku pemberian vaksin (Manutu et al., 2013).
Ciptaan disebarluaskan di bawah

Lisensi Creative Commons Atribusi-

NonKomersial-BerbagiSerupa 4.0 Internasional.

Ibu dengan beberapa anak memiliki lebih banyak pengalaman daripada ibu dengan satu atau dua anak, menyiratkan bahwa ibu dengan banyak anak memiliki lebih banyak pengalaman daripada ibu dengan satu atau dua anak. Ibu akan mendapat manfaat dari ilmu yang didapat serta pengetahuan (Wartisa \& Triveni, 2016).

$\mathrm{Td} 2+$ merupakan kriteria pelayanan kesehatan ibu, Cakupan Td2+ ibu hamil pada tahun 2017 lebih rendah 65,3\% dibandingkan cakupan pelayanan kesehatan K4 ibu hamil yang sebesar $87,30 \%$, menurut Profil Kesehatan Provinsi Jawa Barat (Kementerian Kesehatan RI, 2017b).

Kunjungan ibu hamil ke BPM Ida Ningsih tercatat pada tahun 2021 TT 1 $(34,1 \%)$ dan TT 2 (31,3\%). Pengumpulan data di BPM Ida Ningsih berdasarkan survei awal yang peneliti lakukan pada 20 Agustus 2021 sebanyak 107 kunjungan imunisasi TT 1 dan TT 2 sepanjang tahun 2021. Menurut data, masih ada ibu hamil di wilayah BPM Ida Ningsih yang belum di imunisasi toksoid tetanus. Hal ini dapat disebabkan oleh berbagai faktor, salah satunya adalah kurangnya pengetahuan dan keterampilan akibat rendahnya pelayanan antenatal care dan cakupan vaksin Tetanus 
Toxoid. Faktor predisposisi seperti pengetahuan dan sikap masyarakat terhadap kesehatan, kepercayaan terhadap kesehatan, sistem pendidikan, tingkat sosial, dan sebagainya mempengaruhi perilaku ibu hamil. Kurangnya informasi dan kesadaran ibu tentang manfaat imunisasi Tetanus Toxoid merupakan salah satu faktor yang dapat mempengaruhi penggunaan toksoid tetanus pada ibu hamil.

\section{Metode}

Jenis penelitian ini adalah deskriptif analitik dengan pendekatan
Cross-sectonal. Pengumpulan data dilakukan dengan menggunakan kuesioner tentang hubungan antara paritas dan pengetahuan tentang imunisasi Tetanus Toxoid dengan kelengkapan imunisasi Tetanus Toxoid pada ibu hamil trimester III di BPM Ida Ningsih Tahun 2021. Yang menjadi populasi adalah ibu hamil trimester III yang berkunjung di BPM Ida Ningsih dengan jumlah populasi ibu hamil TT 1 dan TT 2 sebanyak 107 dengan pegambilan sampel dilakukan secara Accidental Sampling yaitu 84 responden. Data di analis dengan uji Chi-Square dengan tingkat kepercayaan 95\%.

\section{Hasil}

Tabel 1. Distribusi Frekuensi Responden Berdasarkan Paritas Imunisasi Tetanus Toxoid

\begin{tabular}{ccc}
\hline Paritas & $\mathbf{n}$ & $\mathbf{\%}$ \\
\hline Rendah & 44 & 52.4 \\
Tinggi & 40 & 47.6 \\
\hline Total & $\mathbf{8 4}$ & $\mathbf{1 0 0}$ \\
\hline
\end{tabular}

Berdasarkan tabel 1 lebih dari $(47,6 \%)$ responden yang memiliki paritas separuh dari $44 \quad(52,4 \%)$ responden tinggi.

memiliki paritas rendah, diikuti oleh 40

Tabel 2. Distribusi Frekuensi Responden Berdasarkan Pengetahuan Imunisasi Tetanus Toxoid 


\begin{tabular}{ccc}
\hline Pengetahuan & $\mathbf{n}$ & $\mathbf{\%}$ \\
\hline Rendah & 34 & 40.5 \\
Tinggi & 50 & 59.5 \\
\hline Total & $\mathbf{8 4}$ & $\mathbf{1 0 0}$ \\
\hline
\end{tabular}

Peneliti dapat menyimpulkan dari tabel 2 bahwa pengetahuan responden rendah, yaitu $34(40,5 \%)$ tidak memiliki pengetahuan. Selanjutnya, lebih dari separuh responden $50(59,5 \%)$ memiliki tingkat pengetahuan yang tinggi.

Tabel 3. Distribusi Frekuensi Responden Berdasarkan Kelengkapan Imunisasi Tetanus Toxoid

\begin{tabular}{ccc}
\hline Kelengkapan Imunisasi & $\mathbf{n}$ & $\mathbf{\%}$ \\
\hline Lengkap & 50 & 59.5 \\
Tidak Lengkap & 34 & 40.5 \\
\hline Total & $\mathbf{8 4}$ & $\mathbf{1 0 0}$ \\
\hline
\end{tabular}

Berdasarkan tabel 3, lebih dari separuh responden $50 \quad(59,5 \%)$ menyelesaikan pengetahuan lengkap tentang toksoid tetanus pada ibu hamil trimester ketiga. Selain itu, 34 (40,5\%) responden mengatakan mereka menyelesaikan prosedur toksoid tetanus pada ibu hamil pada trimester III.

Tabel 4. Hubungan antara Paritas dengan Kelengkapan Imunisasi Tetanus Toxoid pada ibu hamil Trimester III

\begin{tabular}{|c|c|c|c|c|c|c|c|c|}
\hline \multirow{3}{*}{ Paritas } & \multicolumn{4}{|c|}{ Kelengkapan Imunisasi } & & & \multirow{3}{*}{ OR } & \multirow{3}{*}{ P-Value } \\
\hline & \multicolumn{2}{|c|}{ Lengkap } & \multicolumn{2}{|c|}{ Tidak Lengkap } & \multicolumn{2}{|c|}{ Total } & & \\
\hline & $\mathrm{N}$ & $\%$ & $\mathrm{~N}$ & $\%$ & & & & \\
\hline Rendah & 21 & 56.8 & 16 & 43.2 & 37 & 100 & & \\
\hline Tinggi & 23 & 63.9 & 13 & 36.1 & 47 & 100 & 11.700 & 0.002 \\
\hline Total & 32 & 100 & 29 & 100 & 84 & 100 & & \\
\hline
\end{tabular}


Tabel 4 menunjukkan hubungan paritas dengan kelengkapan imunisasi tetanus toksoid pada ibu hamil trimester III di BPM Ida Ningsih tahun 2021. Dari 84 responden paritas rendah terdapat 37 responden dengan imunisasi lengkap 21
Ciptaan disebarluaskan di bawah

Lisensi Creative Commons Atribusi-

NonKomersial-BerbagiSerupa 4.0 Internasional

Tabel 5. Hubungan antara Pengetahuan dengan Kelengkapan Imunisasi Tetanus Toxoid pada ibu hamil Trimester III

\begin{tabular}{|c|c|c|c|c|c|c|c|c|}
\hline \multirow{3}{*}{ Paritas } & \multicolumn{4}{|c|}{ Kelengkapan Imunisasi } & \multirow{2}{*}{\multicolumn{2}{|c|}{ Total }} & \multirow{3}{*}{ OR } & \multirow{3}{*}{ P-Value } \\
\hline & \multicolumn{2}{|c|}{ Lengkap } & \multicolumn{2}{|c|}{ Tidak Lengkap } & & & & \\
\hline & $\mathrm{N}$ & $\%$ & $\mathrm{~N}$ & $\%$ & & & & \\
\hline Rendah & 17 & 38.6 & 27 & 61.4 & 44 & 100 & & \\
\hline Tinggi & 15 & 37.5 & 25 & 62.5 & 40 & 100 & 8.708 & 0.006 \\
\hline Total & 32 & 62 & 52 & 38 & 84 & 100 & & \\
\hline
\end{tabular}

Tabel 5 menunjukan usia di wilayah kerja BPM Sri Puspa Kencana, Amd.Keb dari 157 sampel menunjukan bahwa usia produktif sebanyak $88(56,1 \%)$ dan usia non produktif $69(43,9 \%)$.

\section{Pembahasan}

Berdasarkan hasil penelitian lebih dari separuh dari $44(41,1 \%)$ responden memiliki paritas rendah, sedangkan 40 $(37,4 \%)$ memiliki paritas tinggi. Penelitian ini mengungkapkan bahwa mayoritas ibu hamil adalah multipara. Hal ini disebabkan oleh fakta bahwa kelompok paritas
$(56,8 \%)$ dan $16 \quad(43,2 \%)$ responden imunisasi tidak lengkap. Responden imunisasi dengan paritas tinggi sebanyak 36 , dengan rincian $23(63,9 \%)$ responden imunisasi lengkap dan $13 \quad(36,1 \%)$ responden imunisasi tidak lengkap. 
JOURNAL OF MIDWIFERY CARE :

VOL. 02 No. 01, DESEMBER 2021

DOI : $\underline{10.34305 / J M C . V 2 I 01.361}$

lebih siap untuk memberikan lebih banyak perawatan dan tanggung jawab. Sebaliknya, ibu yang pernah hamil dua kali atau lebih cenderung kurang memperhatikan idenya atau sebaliknya (Riri Parti Ningsih, 2017)

Berdasarkan hasil peneliti dapat menyimpulkan bahwa $34 \quad(31,8 \%)$ responden memiliki pengetahuan rendah Selanjutnya, lebih dari separuh responden $50(46,7 \%)$ memiliki tingkat pengetahuan tinggi. Menurut hasil penelitian, pengetahuan dipelajari tidak hanya melalui sarana resmi, tetapi juga melalui konseling, teman, dan brosur, dan semakin banyak pemahaman tentang pemberian toksoid tetanus pada anak, semakin besar kemungkinan anak tersebut menerima toksoid tetanus. Ibu individu merupakan salah satu faktor yang mempengaruhi pemberian vaksin tetanus toksoid. Semakin besar pemahaman ibu tentang pentingnya kesehatan, semakin besar kemungkinan mereka untuk berpartisipasi dalam kegiatan posyandu atau imunisasi (Wawan \& Dewi, 2018).

Sebagian besar dari 50 (46,7\%) responden telah mendapatkan imunisasi Tetanus Toksoid lengkap pada ibu hamil trimester III. Selanjutnya, 34 (31,8\%) responden mengatakan vaksin Tetanus
Ciptaan disebarluaskan di bawah

Lisensi Creative Commons Atribusi-

NonKomersial-BerbagiSerupa 4.0 Internasional.
Toxoid mereka tidak lengkap pada trimester III kehamilan. Imunisasi Tetanus Toxoid (TT) merupakan salah satu teknik untuk mencegah terjadinya infeksi Tetanus. Vaksin tetanus terdiri dari toksin tetanus murni dan dilemahkan. Tetanus toksoid disarankan untuk mencegah tetanus bayi. Imunisasi tetanus yang diberikan pada saat pemeriksaan dapat menurunkan kematian neonatus dan menghindari kematian ibu terkait tetanus (Mandriwati, 2008).

Tetanus neonatorum adalah sejenis penyakit tetanus yang menyerang bayi dan anak-anak. Clostridium tetani, bakteri yang menghasilkan toksin (toksin) dan menyerang sistem saraf pusat, menyebabkan Tetanus neonatorum, sejenis tetanus yang menyerang bayi. Lindungi ibu dari tetanus jika dia terluka. Manfaat ini merupakan salah satu sarana yang digunakan untuk mencapai salah satu tujuan program nasional kedua, yaitu mengeliminasi tetanus ibu dan bayi baru lahir (Bartini, 2012).

Berdasarkan hasil uji statistik dengan nilai $\mathrm{p}$ value $0,002(\mathrm{p})$, terdapat hubungan antara paritas dengan pengetahuan ibu hamil trimester III di BPM Ida Ningsih tahun 2021. Dari analisis diperoleh nilai OR sebesar 11.700 
JOURNAL OF MIDWIFERY CARE :

VOL. 02 No. 01, DESEMBER 2021

DOI : $\underline{10.34305 / J M C . V 2 I 01.361}$
Ciptaan disebarluaskan di bawah

Lisensi Creative Commons Atribusi-

NonKomersial-BerbagiSerupa 4.0 yang berarti responden dengan paritas memiliki peluang 11,700 kali untuk berkembang dibandingkan dengan mereka yang memiliki paritas tinggi.

Menurut asumsi penelitian paritas, hal itu berdampak besar pada kesadaran masyarakat akan penelitian toksoid tetanus. Paritas terendah terdapat pada paritas primipara pada penelitian ini karena tidak mengetahui adanya serangan tetanus toksoid, sehingga ada responden yang tidak mematuhi pemeriksaan toksoid tetanus ke fasilitas pelayanan kesehatan terdekat dan memiliki pemahaman tentang risiko yang terjadi. setelah mengalami serangan tetanus toksoid. Ibu yang hamil untuk pertama kalinya akan melalui masa pematangan, yang mungkin sulit, tetapi mereka akan lebih siap untuk memberikan lebih banyak perawatan dan tanggung jawab. Karena wanita multipara telah mengalami kehamilan ganda dan melahirkan, mereka lebih menyadari manfaat dari toksoid tetanus.

Penelitian ini sejalan dengan penelitian Yunica tahun 2016, tentang hubungan antara paritas dengan kelengkapan imunisasi Tetanus Toxoid pada ibu hamil di Desa Sungai Dua tahun 2014, didapatkan hail $p$ value 0,002 adanya hubungan antara paritas dengan kelengkapan imunisasi Tetanus Toxoid pada ibu hamil (Yunica, 2015).

Berdasarkan hasil uji statistik dengan nilai $\mathrm{p} 0,006$ (p), terdapat hubungan antara kesadaran imunisasi tetanus toksoid dengan selesainya imunisasi tetanus toksoid pada ibu hamil trimester III di BPM Ida Ningsih tahun 2021. Penelitian ini menghasilkan OR sebesar 8.708, menunjukkan bahwa individu dengan pengetahuan sedikit memiliki kemungkinan 8.708 kali lipat lebih tinggi untuk imunisasi tidak lengkap dibandingkan mereka yang memiliki pengetahuan baik.

Menurut hipotesis penelitian, mengetahui cara melakukan percobaan tetanus pada penyakit tetanus memerlukan pemahaman ibu hamil. Studi ini menilai bahwa pengetahuan diperoleh tidak hanya melalui instruksi formal, tetapi juga melalui konselor, teman, dan brosur, dan bahwa semakin banyak pemahaman tentang informasi tetanus toksoid, semakin besar kemungkinan percobaan tetanus toksoid pada ibu hamil (Notoadmodjo, 2019).

Penelitian ini sejalan dengan penelitian Fitriah tahun 2017, tentang perilaku ibu hamil terhadap imunisasi Tetanus Toxoid di Puskesmas Tangse 
JOURNAL OF MIDWIFERY CARE :

VOL. 02 No. 01, DESEMBER 2021

DOI : $\underline{10.34305 / J M C . V 2 I 01.361}$
Ciptaan disebarluaskan di bawah

Lisensi Creative Commons Atribusi-

NonKomersial-BerbagiSerupa 4.0 Internasional.
Kabupaten Pidie, didapatkan hasil penelitian $\mathrm{p}$ value 0,038 dapat disimpulkan adanya hubungan antara pengetahuan dengan perilaku ibu hamil terhadap imunisasi Tetanus Toxoid (Wartisa \& Triveni, 2016).

Salah satu hal yang mempengaruhi pemberian tehnik tetanus toksoid adalah tingkat pemahaman ibu yang berdampak pada perilaku individu. Semakin besar pemahaman $\mathrm{ibu}$ tentang pentingnya kesehatan, semakin besar kemungkinan mereka untuk berpartisipasi dalam kegiatan atau senam posyandu. Responden dengan pengetahuan rendah melakukan kelengkapan imunisasi tetanus toksoid dalam penelitian ini yaitu yang bekerja sebagai ibu rumah tangga, dibandingkan responden dengan pengetahuan tinggi karena sebagian besar responden memiliki pekerjaan tetap. Setiap bulan di posyandu, diadakan kunjungan.

\section{Kesimpulan}

Lebih dari $44(41,1 \%)$ responden memiliki paritas rendah, sedangkan 40 $(37,4 \%)$ memiliki paritas tinggi, pengetahuan responden rendah, yaitu 34 $(31,8 \%)$ tidak memiliki pengetahuan. Selanjutnya, lebih dari separuh responden $50(46,7 \%)$ memiliki tingkat pengetahuan
tertentu.Lebih dari setengah dari 50 $(46,7 \%)$ responden yang sudah lengkap melakukan imunisasi Tetanus Toxoid pada ibu hamil trimester III. Selanjutnya, 34 $(31,8 \%)$ responden tidak lengkap melakukan imunisasi Tetanus Toxoid pada ibu hamil trimester III.

Berdasarkan hasil uji statistik $\mathrm{p}=$ 0,002 (p), dapat disimpulkan bahwa ada hubungan antara paritas dengan pengetahuan ibu hamil trimester III di BPM Ida Ningsih tahun 2021. Berdasarkan hasil penelitian, responden dengan paritas rendah memiliki kemungkinan menyelesaikan 11,700 kali lebih sering dibandingkan dengan paritas tinggi. Hasil uji statistik diperoleh nilai $\mathrm{p}$ value $0,006(\mathrm{p})$, yang menunjukkan bahwa ada hubungan antara pengetahuan imunisasi Tetanus Toksoid dengan ibu hamil trimester III di BPM Ida Ningsih tahun 2021. Berdasarkan statistik, OR = 8.708 artinya responden dengan pengetahuan kurang memiliki kemungkinan ketidaklengkapan 11,700 kali lebih tinggi daripada mereka yang berpengetahuan baik.

\section{Saran}

Temuan penelitian ini dapat membantu meningkatkan pemahaman 
JOURNAL OF MIDWIFERY CARE :

VOL. 02 No. 01, DESEMBER 2021

DOI : $\underline{10.34305 / J M C . V 2 I 01.361}$
Ciptaan disebarluaskan di bawah

Lisensi Creative Commons Atribusi-

NonKomersial-BerbagiSerupa 4.0 tentang hubungan paritas dengan pengetahuan teknik Tetanus Toxoid pada ibu hamil trimester III di BPM Ida Ningsih di tahun 2021. Bagi Institut pendidikan, ttemuan penelitian ini dapat digunakan sebagai informasi dan masukan dalam fasilitas pembelajaran, serta memberikan ide untuk melakukan penelitian tambahan pada berbagai topik dan sebagai data awal bagi peneliti selanjutnya. Bagi Bidan Praktik Mandiri, temuan penelitian ini dapat dimanfaatkan oleh tenaga kesehatan di Wilayah Kerja BPM Ida Ningsih tahun 2021 untuk memberikan pengetahuan dan masukan untuk penyuluhan. Bagi Responden, temuan penelitian ini dapat meningkatkan pengetahuan ibu tentang pentingnya penggunaan toksoid tetanus untuk menghindari tetanus bayi baru lahir.

\section{Referensi}

bartini, I. (2012). Asuhan Kebidanan Pada Ibu Hamil Normal. Yogyakarta: Nuha Medika.

Dinas Kesehatan. (2018). Profil Kesehatan Indonesia. Departemen Kesehatan Republik Indonesia.

Kementerian Kesehatan Ri. (2017a). Angka Kematian Ibu Dan Bayi. Http://Jurnal.Kemkes.Angka-

Kematian-Ibu-DanBayi.Ac.Id/Index.Php/Jkma/Article/V iew/80/86
Kementerian Kesehatan Ri. (2017b). Buletin Jendela Data Dan Informasi Eliminasi Tetanus Maternal Dan Neonatal.

Lisnawati, L. (2011). Generasi Sehat Melalui Imunisasi. Jakarta: Trans Info Media.

Mandriwati, G. A. (2008). Penuntun Belajar Asuhan Kebidanan Ibu Hamil. Jakarta: Egc.

Manutu, J., Korah, B. H., \& Pesak, E. (2013). Hubungan Pengetahuan Ibu Dengan Pemberian Imunisasi Tetanus Toxoid Di Puskesmas Rurukan Kecamatan Tomohon Timur Kota Tomohon. Jidan (Jurnal Ilmiah Bidan), 1(1), 31-35.

Notoadmodjo. (2019). Pengantar Ilmu Perilaku Kesehatan. Jakarta: Rineka Cipta, 72-91.

Profil Kesehatan Dinkes Kota Bogor. (2017). Data Kunjungan Pelayanan Kebidanan.

Http://Bppsdmk.Dinkes.Pelayanan-

Kebidanan-Kota-

Bogor.Go.Id/Index.Php/1665/30

Riri Parti Ningsih, R. P. N. (2017). Hubungan Paritas Dan Pengetahuan Tentang Imunisasi Tetanus Toxoid Dengan Kelengkapan Imunisasi Tetanus Toxoid Pada Ibu Hamil Trimester Iii Di Puskesmas Plus Mandiangin Bukittinggi Tahun 2017. Stikes Perintis Padang.

Wartisa, F., \& Triveni, T. (2016). Hubungan Paritas Dan Pengetahuan Tentang Imunisasi Tetanus Toxoid Dengan Kelengkapan Imunisasi Tetanus Toxoid Pada Ibu Hamil 
Trimester Iii Di Puskesmas Plus Mandiangin Bukittinggi. Jurnal Kesehatan Perintis (Perintis's Health Journal), 3(1), 1-7.

Wawan, A., \& Dewi, M. (2018). Teori \& Pengukuran Pengetahuan, Sikap, Dan Perilaku Manusia Dilengkai Contoh Kuesioner. ed. Jhon Budi. Yogyakarta: Nuha Medika.

World Health Organization (WHO). (2018). Angka Kematian Ibu dan
Bayi. http://jurnal.who-akiakb.go.id/index.php/jbp/download/4/4

Yunica, J. A. (2015). Hubungan antara pengetahuan dan umur dengan kelengkapan imunisasi Tetanus Toxoid (TT) pada ibu hamil di Desa Sungai Dua Kecamatan Rambutan Kabupaten Banyuasin tahun 2014. Jurnal Kedokteran Dan Kesehatan: Publikasi Ilmiah Fakultas Kedokteran Universitas Sriwijaya, 2(1), 93-98. 